\title{
HOBI EKSTRIM PECINTA REPTIL: Studi Antropologi Budaya pada Komunitas Animal Lovers di Kota Lhokseumawe
}

\author{
Indri Purnamasari ${ }^{1}$, Iromi Ilham ${ }^{2}$ \\ 1,2 Program Studi Antropologi, Universitas Malikussaleh Lhokseumawe \\ Aceh-Indonesia
}

Korespondensi: indripurnamasari709@gmail.com

\begin{abstract}
Abstrak: Salah satu hobi yang berkembang saat ini ialah memelihara hewan liar jenis reptil. Bagi sebahagian masyarakat, hewan tersebut dianggap membahayakan, namun bagi sebahagian yang lain, malah dianggap sebagai "sahabat" sehingga ada yang memelihara dan merawatnya dengan baik, bahkan menjadi hobi yang dicintai. Hobi memelihara reptil memunculkan varian perilaku yang berbasis pada berbagai motivasi dan tujuan yang berkorelasi dengan pandangan hidup (nilai) dan budaya masing-masing masyarakat. Oleh karena itu, tulisan ini mengkaji tentang bagaimana perilaku hobi ekstrim pecinta reptil dengan fokus kajian pada Komunitas Animal Lovers di Kota Lhokseumawe. Penelitian yang menggunakan pendekatan antropologi budaya ini menggunakan metode kualitatif deskriptif dengan teknik pengumpulan data observasi, wawancara mendalam, studi dokumen, dan literatur. Tujuan dari penelitian ini adalah untuk mengetahui motif dan nilai penting dari lahirnya komunitas tersebut serta untuk mengetahui bagaimana hubungan atau relasi yang terjalin antara manusia dengan hewan. Hasil penelitian menunjukkan bahwa ada beberapa nilai penting yang menjadi latar belakang lahirnya komunitas Animal Lovers Lhokseumawe, di antaranya: (1) nilai budaya, (2) nilai sosial, (3) nilai pendidikan (edukasi), (4) nilai seni (hiburan), dan (5) nilai eksistensi. Kemudian berdasarkan motif dan nilai dalam pelaksanaan kegiatan hobi tersebut, ada beberapa perilaku yang menunjukkan ekspresi sayang terhadap hewan di kalangan Animal Lovers Lhokseumawe, diantaranya adalah; perhatian terhadap hewan (menjaga kebersihan, memberi makan, dan menyediakan tempat tinggal), dan bermain dengan reptil. Perilaku tersebut cenderung menampilkan wujud relasi manusia dengan hewan di kalangan dalam memelihara reptil.
\end{abstract}

Kata Kunci: Hobi Ekstrim, Reptil, Nilai Budaya, dan Komunitas Animal Lovers 


\section{A. Pendahuluan}

Hobi berasal dari kata bahasa Inggris yaitu "Hobby". Menurut KBBI (Kamus Besar Bahasa Indonesia) kata hobi berarti kegemaran, kesenangan istimewa yang dilakukan pada waktu senggang. Menurut @jaga.id, hobi merupakan suatu kegiatan kasual yang dilakukan secara teratur, dan dikerjakan untuk mendapatkan kesenangan diri. Biasanya kegiatan tersebut dilakukan atas dasar ketertarikan yang sangat kuat dari dalam diri manusia. Hobi pada setiap individu tentunya memiliki tujuan serta manfaat yang ingin dirasakan oleh para pelaku. Salah satu jenis hobi yang sedang marak yaitu hobi memelihara hewan.

Hewan merupakan bagian yang tidak terpisahkan dari kehidupan manusia. Hubungan atau relasi antara hewan dengan manusia sering terjadi perubahan dari masa ke masa. Sejarah paling pertama hubungan ini tercatat pada zaman The Stone Age atau zaman batu. Fungsi hewan peliharaan adalah untuk membantu pekerjaan manusia. Anjing untuk berburu, sapi untuk menggarap sawah, kuda sebagai alat transportasi. Namun seiring waktu berjalan, hubungan di antara manusia dan hewan peliharaan menjadi lebih kompleks. Hewan dipelihara tidak hanya untuk membantu manusia saja, tetapi juga atas azas hubungan emosional, bahkan untuk meningkatkan status sosial.

Perilaku memperlakukan hewan secara lebih ini bagi sebagian manusia dijadikan sebagai status sosial. Jenis hewan yang dipelihara pun bisa menjadikan status sosial yang berbeda. Jika hewan yang dipelihara merupakan kualitas yang terbaik dan mahal maka status sosial pemiliknya juga akan jauh lebih tinggi daripada yang hanya memelihara hewan biasa. Terkadang status sangat penting dan berharga bagi sebagian manusia. Banyak hewan-hewan mahal yang dibeli dan dijadikan hewan peliharaan hanya untuk menaikan pamor kekayaan atau hanya sebagai kesenangan semata. Beberapa masyarakat tertarik dalam memelihara hewan-hewan eksotis seperti hewan reptile, hal ini dikarenakan jenis reptile yang beraneka ragam dan mahal harganya. Reptil sendiri merupakan salah satu hewan vertebrata yang memiliki tulang belakang dan berdarah dingin. Hewan ini dapat menyesuaikan suhu tubuhnya sendiri. Dikutip dari profauna.net, bahwasanya di Indonesia diperkirakan ada sekitar 350.000 jenis hewan, di antaranya terdapat 2.000 jenis reptilian. 
Salah satu hobi yang berkembang saat ini ialah memelihara hewan jenis reptil. Seperti yang dilakukan oleh masyarakat yang tergabung dalam komunitas Animal Lovers di Lhokseumawe. Animal Lovers Lhokseumawe (ALL) merupakan suatu komunitas yang terdiri dari mahasiswa yang mencintai hewan melata. Komunitas ini beranggotakan 19 orang yang mana semuanya menyukai reptil serta memiliki hewan reptil.

Hal tersebut di atas memotivasi peneliti untuk melakukan penelitian ini. Karena, kegiatan yang dilakukan oleh para anggota komunitas tersebut menjadi suatu hal yang tidak lazim. Keadaan ini menjadikan hobi ekstrim komunitas Animal Lovers Lhokseumawe sebagai suatu tindakan dan perilaku yang amat unik untuk diteliti. Oleh karena itu, tulisan ini akan mengupas tentang apa saja nilai penting yang mendorong lahirnya komunitas Animal Lovers di Kota Lhokseumawe; serta bagaimana relasi antara manusia dan binatang pada komunitas Animal Lovers Lhokseumawe.

\section{B. Metode}

Penelitian ini dilakukan di Kota Lhokseumawe dengan dua tempat sebagai lokus utama. Pertama, Taman Riyadhah yang berada di Jalan Merdeka. Berdasarkan hasil pengamatan, tempat ini menjadi lokasi yang sering diadakannya gathering oleh Animal Lovers Lhokseumawe. Kemudian lokasi kedua yakni di daerah Kuta Blang tepatnya di Jalan Mahoni Gg Jambu, No 42, rumah milik salah satu anggota Komunitas Animal Lovers Lhokseumawe yang digunakan untuk menyimpan hewanhewan reptil tersebut.

Penelitian ini merupakan penelitian sosial kualitatif yang menggunakan metode kualitatif deskriptif, yang mana datanya berupa penjabaran atau ulasan yang bersifat deskriktif. Penelitian kualitatif ini adalah penelitian yang bermaksud untuk memahami fenomena tentang apa yang dialami oleh subjek penelitian, misalnya perilaku, persepsi, motivasi, tindakan dan lain sebagainya. Fenomena tersebut akan dideskripsikan secara holistik dalam bentuk kata dan bahasa, pada suatu konteks khusus yang alamiah dan dengan memanfaatkan berbagai metode alamiah (Moleong $2014: 6)$. 
Penelitian ini menggunakan pendekatan fenomenologi. Pendekatan fenomenologi merupakan pandangan berpikir yang menekankan pada fokus terhadap pengalaman-pengalaman subjektif manusia dan interpretasi-interpretasi dunia (Moleong 2014:15). Artinya, penelitian fenomenologi berusaha memahami budaya melalui pandangan pemilik budaya atau pelakunya (Endraswara 2006: 65). Untuk mendapatkan data dan informasi yang diperlukan, peneliti menggunakan empat macam teknik pengumpulan data, diantaranya; Observasi partisipatif (participant observation), wawancara, studi dokumen dan studi literatur.

\section{Pembahasan}

\section{Komunitas Animal Lovers Lhokseumawe}

Komunitas Animal Lovers merupakan satu-satunya komunitas pecinta reptil yang berada di Kota Lhokseumawe. Komunitas ini awalnya merupakan sebuah komunitas pecinta kucing yang dinamakan 'KoPet' (Komunitas Pet). Komunitas ini beranggotakan para siswa serta mahasiswa yang mencintai kucing dan hewan peliharaan lainnya. namun seiring berjalannya waktu minat dan antusias masyarakat terhadap kucing mulai menurun yang mana berakibat kepada sepi dan vakum sehingga eksistensi aktivitas dari komunitas ini memudar. Setelah beberapa lama vakum salah seorang anggota mempunyai ide serta niat untuk membentuk kembali sebuah komunitas pecinta hewan namun dengan objek utama yaitu hewan reptil. Sehingga komunitas ini diubah menjadi sebuah komunitas pecinta hewan yang lebih memfokuskan kepada pecinta reptil.

Pada tanggal 15 September 2016 terbentuklah komunitas "Animal Lovers Lhokseumawe" yang beranggotakan 6 orang. Lambat laun dengan melakukan gathering banyak masyarakat khususnya dari siswa dan mahasiswa yang ingin bergabung ke dalam komunitas ini. Setiap para calon anggota yang ingin bergabung harus memenuhi syarat tertentu yakni, (1) Setiap calon anggota wajib mempunyai hewan peliharaan pribadi. (2) Setiap anggota wajib bertanggung jawab terhadap hewan peliharaannya. (3) Setiap hewan peliharaan harus didaftarakan kepada komunitas dan tidak boleh diperjual-belikan. (4) Setiap hewan peliharaan yang mati maka pemiliknya akan mendapatkan konsekuensi yang berlaku. 


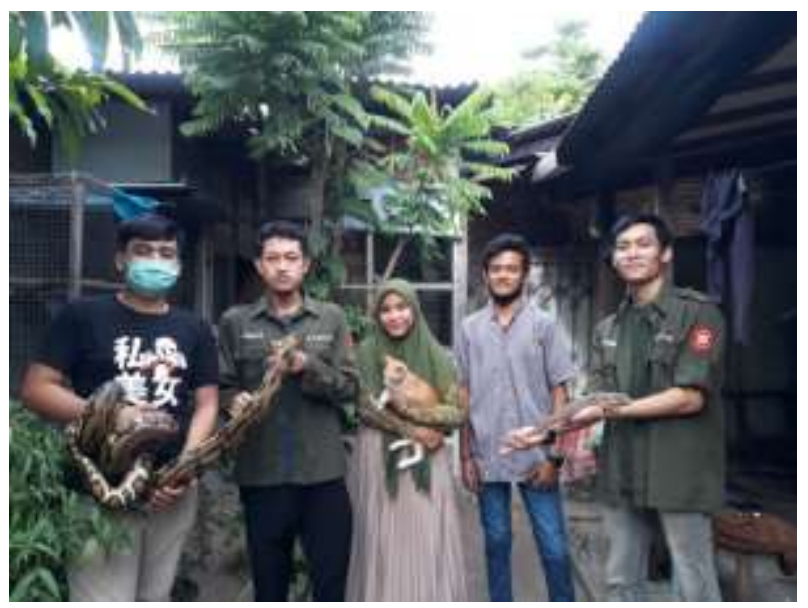

Gambar 1. Komunitas Animal Lovers Kota Lhokseumawe

Komunitas Animal Lovers Lhokseumawe (ALL) merupakan komunitas nonprofit (non formal). Komunitas ini berdiri sendiri tanpa ada ikatan atau hubungan dengan dinas atau lembaga manapun. Tidak hanya itu saja komunitas ini juga tidak memberlakukan anggaran dasar/ anggaran rumah tangga (AD/ART) pada komunitasnya. Walaupun komunitas ini non profit namun mereka tetap membentuk badan struktur organisasi mulai dari ketua hingga jajarannya. Komunitas Animal Lovers Lhokseumawe beranggotakan 19 orang. Komunitas ini beranggotakan dari semua kalangan dan berbagai latar belakang budaya, profesi dan daerah yang berbeda-beda. Komunitas Animal Lovers Lhokseumawe terbentuk karena adanya kesamaan hobi dari setiap individu.

Komunitas ini juga memiliki beberapa peraturan dasar yang harus dipatuhi oleh para anggota Komunitas Animal Lovers Lhokseumawe. Peraturan tersebut dibuat dengan kesepakatan dari hasil musyawarah seluruh anggota komunitas Animal Lovers Lhokseumawe. Peraturan-peraturan itu dibuat dengan tujuan agar komunitas ini lebih teratur serta mempermudah jalannya kegiatan rutinitas seperti gathering dan segala hal yang berkaitan dengan komunitas.

\section{Jenis-Jenis Hewan Peliharaan Komunitas ALL}

Salah satu syarat utama agar dapat bergabung dalam komunitas Animal Lovers Lhokseumawe adalah wajib mempunyai hewan peliharaan pribadi. Karena itu setiap anggota memiliki hewan peliharaan masing-masing. Jenis dan jumlah hewan peliharaan sesuai dengan hewan apa yang disukai oleh masing-masing anggota. 
Namun secara umum, adapun beberapa jenis hewan yang dipelihara oleh komunitas ini yaitu:

a. Ular (Serpentes)

Ular adalah kelompok reptilia tidak berkaki dan bertubuh panjang yang tersebar luas di dunia. Ular merupakan hewan karnivora yang memakan daging dan hewan-hewan kecil lainnya. Komunitas Animal Lovers Lhokseumawe memelihara ular dengan berbagai jenis, di antaranya:

- Python Reticulatus normal (4 Meter)

- Python Reticulatus Albino Purple (2,5 Meter)

- Python Reticulatus Tiger ( 2.7 Meter)

- Python Reticulatus Phantom (2.5 Meter)

- Python Reticulatus Super Tiger (2,3 Meter)

- Python Reticulatus Platynum Super Dwarf 50\% (1,7 Meter)

- Boa pembelit (Boa Constrictor) $75 \mathrm{~cm}$

b. Kadal (Lacertilia)

Kadal atau bengkarung adalah kelompok reptilia bersisik berkaki empat (beberapa spesies tidak berkaki dan mirip ular, tetapi bukan ular) yang tersebar sangat luas di dunia. Kadal merupakan hewan yang omnivora yakni memakan daging dan tmbuhan. Komunitas Animal Lovers Lhokseumawe hanya memelihara beberapa jenis kadal yang dipelihara yakni:

- Biawak air (Varanus Salvator)

- Tokek (Gekko-gecko)

c. Tarantula (Theraphosidae)

Tarantula adalah nama yang diberikan untuk salah satu jenis laba-laba dengan ukuran sangat besar yang umumnya berambut. Laba-laba ini masuk pada famili Theraphosidae dan paling tidak ada sekitar 800 spesies yang telah berhasil diidentifikasi. Sebagian tarantula tidak berbahaya bagi manusia serta tarantula biasanya hidup di bawah tanah dan pohon. Sebagian jenis tarantula banyak yang diperdagangkan karena jenis yang eksotik.

d. Kura-kura (Testudines)

Kura-kura adalah hewan bersisik berkaki empat yang termasuk golongan reptil. Bangsa hewan yang disebut (ordo) Testudinata (atau Chelonians) ini khas 
dan mudah dikenali dengan adanya 'rumah' atau batok (bony shell) yang keras dan kaku. Kura-kura ada yang bersifat pemakan tumbuhan (herbivora), pemakan daging (karnivora) atau campuran (omnivora). Kura-kura biasanya hidup di rawa, laut dan sebagian ada yang hidup di tanah. Kura-kura merupakan jenis hewan yang bertelur. Kura-kura akan bertelur di dalam tanah dengan menggalinya dan menetaskan telurnya di dalam tanah.

e. Tupai terbang (Pteromyni)

Tupai terbang merupakan salah satu dari jenis tupai yang meiliki kemampuan untuk terbang. Mereka hanya bisa terbang dari satu pohon ke pohon lainnya dengan menggunakan bantuan selaput pada tangan dan kaki yang terhubung ke ekornya sehingga dapat menyeimbangkan tubuhnya. Tupai terbang merupakan jenis mamalia pengerat. Makanan tupai terbang yaitu buah-buahan, kacang-kacangan dan ular kecil.

\section{f. Landak mini (Erinaceinae)}

Landak mini merupakan hewan mamalia yang aktif di malam hari. Hewan ini merupkan pemakan serangga. Walaupun satu spesies dengan landak biasanya yang mempunyai duri tajam pada tubuhnya namun landak mini berbeda karena duri pada tubuhnya tidak tajam dan aman jika dipegang. Tidak hanya itu, bentuk tubuhnya yang kecil dan menggemaskan membuat banyak orang ingin memeliharanya.

\section{g. Musang (Paradoxurus)}

Musang merupakan hewan mamalia yang aktif pada malam hari. Musang termasuk hewan karnivora namun beberapa lainnya merupakan herbivora yaitu pemakan buah-buahan.

\section{Nilai Penting Lahirnya Komunitas Animal Lovers Lhokseumawe}

Nilai adalah konsep yang menunjuk pada hal-hal yang dianggap berharga dalam kehidupan manusia, yaitu tentang apa yang dianggap baik, layak, pantas, benar, penting, indah, dan dikehendaki oleh masyarakat dalam kehidupan seharihari. Keberadaannya dicita-citakan, diinginkan, dihayati, dan dilaksanakan dalam kehidupan sehari hari dan menjadi tujuan kehidupan bersama di dalam kelompok masyarakat tersebut, mulai dari unit kesatuan sosial terkecil hingga yang terbesar, 
mulai dari lingkup suku, bangsa, hingga masyarakat internasional. (Hanapi, 2017; 94-95).

Sebagaimana ungkapan Abraham Maslow (1908-1970) dalam konsep hierarki kebutuhan, bahwa semua motivasi terjadi sebagai reaksi atas persepsi seseorang individu atas lima macam tipe dasar kebutuhan. Ada beberapa nilai penting terbentuknya serta melahirkan komunitas Animal Lovers Lhokseumawe. Di antaranya nilai-nilai tersebut ialah:

1. Nilai Budaya

Koentjaraningrat (dalam Ningsih, 2017) mendefinisikan nilai budaya sebagai konsepsi-konsepsi yang hidup dalam alam pikiran sebagain besar warga masyarakat menangani hal-hal yang dianggap mulia, bernilai, berharga, dan penting dalam hidup mereka. Dalam suatu komunitas, terdapat nilai-nilai budaya yang saling berkaitan satu dengan lainnya. Sehingga membentuk suatu sistem nilai budaya yang dijadikan sebagai konsep-konsep ideal yang dapat memotivasi dan mengarahkan komunitas tersebut.

Merujuk pada konsep nilai budaya yang dirumuskan oleh F. Kluckhon dalam Koentjaraningrat $(2009 ; 54)$ hasil kajian tentang orientasi nilai budaya komunitas Animal Lovers Lhokseumawe (ALL) menunjukkan beberapa aspek yang menjadi dasar motivasi pembentukan komunitas Animal Lovers serta dorongan terhadap pelaksanaan setiap kegiatan. Dan aktivitas-aktivitas atau kegiatan tersebut merupakan sesuatu yang dilakukan secara sadar oleh setiap anggota komunitas. Hal tersebut dapat terlihat dari bentuk-bentuk perilaku dan sikap yang dibangun dalam setiap anggota komunitas tersebut. Keadaan ini dapat dijelaskan sebagai berikut.

a. Masalah hakikat hidup

Mensinkronisasikan hasil penelitian tentang orientasi nilai budaya komunitas Animal Lovers Lhokseumawe dengan motivasi memelihara reptil sebagai hobi menunjukkan peningkatan motivasi belajar dari setiap anggota komunitas dalam usaha memahami dunia reptile melalui proses sharing edukasi reptil terhadap sesama anggota komunitas dan masyarakat. Ini salah satu cara positif mereka dalam memandang proses menuju tercapainya tujuan hidup lebih baik dengan berguna terhadap sesama. Pola perilaku tersebut ditunjukkan dengan adanya rasa saling membantu dalam bermasyarakat. 


\section{b. Masalah hakikat dari karya manusia}

Dengan memberikan muatan motivasi belajar pada setiap anggota mengenai hal yang berkaitan dengan hewan peliharaannya dan skill lainnya yang dibutuhkan, anggota komunitas akan memperoleh keterampilan sebagai modal berkarya. Hal ini lebih mengarah pada terbentuknya self expression yakni kemampuan untuk mengekspresikan diri. Sehingga setiap anggota bisa menikmati apa yang sedang ditekuni serta dapat membagikan pengalamannya kepada orang lain melalui proses sharing, sosialisasi dan edukasi. Artinya komunitas ALL mampu mengaktualisasikan hasil belajarnya sebagai praktek berkarya sebagai usaha untuk mempertinggi prestasi.

c. Masalah hakikat dari kedudukan manusia dalam ruang waktu

Mengenai masalah kedudukan manusia dalam ruang waktu, komunitas ALL berorientasi pada masa kini. Implementasi hakikat ruang dan waktu terhadap motivasi pembentukan komunitas Animal Lovers Lhokseumawe lebih ditekankan pada kemampuan anggota komunitas dalam membangun dan mewujudkan harapan untuk memanfaatkan hidup yang bermanfaat di masa kini. Dan waktu diyakini dapat mengantarkan komunitas ALL ke dalam harapan tersebut. Harapan untuk berkembang dalam mempengaruhi masyarakat dalam melihat reptil yakni menciptakan kehidupan masyarakat yang dapat hidup berdampingan dengan hewan.

d. Masalah hakikat dari hubungan manusia dengan alam sekitarnya

Berkenaan dengan hubungan manusia dengan alam, komunitas Animal Lovers Lhokseumawe beranggapan bahwa manusia sepatutnya tunduk pada alam (subjugation to nature). Hal ini dikarenakan pemahaman akan pemenuhan kebutuhan hidup manusia masih bergantung pada alam. Komunitas ini menyadari bahwa manusia saat ini tunduk kepada alam. Dengan menciptakan kebiasaankebiasaan bersahabat dengan reptil. Hal ini didasari dengan memandang dampak terhadap keseimbangan alam dan ekosistem rantai makanan. Jika ekosistem dan rantai makanan terganggu atau rusak maka manusia akan kesulitan.

e. Masalah hakikat dari hubungan manusia dengan sesama.

Hubungan manusia dengan sesama pada komunitas ALL berorientasi kolateral (horizontal), yakni rasa ketergantungan kepada sesamanya. Komunitas 
ALL menyadari bahwa manusia sangat bergantung pada manusia yang lain sehingga saling membantu antara satu sama lainnya. Yang kemudian hal tersebut menciptakan nilai atas sikap atau perilaku, yaitu rasa solidaritas dan kekeluargaan serta saling membantu.

\section{Nilai Sosial}

Pada dasarnya manusia merupakan makhluk sosial. Sosial sangat erat kaitannya dengan komunitas, hal ini dikarenakan setiap komunitas ada interaksi sosial di dalamnya. Interaksi sosial sebagai perwujudan dari hubungan manusia dengan sesama. Yang kemudian proses tersebut menciptakan nilai atas sikap atau perilaku, yaitu;

\section{a. Nilai Solidaritas dan kekeluargaan}

Sebuah komunitas tidak luput dari rasa atau ikatan dari hati yang tumbuh secara alami. Sesama anggota memiliki rasa solidaritas yang tinggi. Bahkan rasa solidaritas ini meluas bukan hanya sesama anggota komunitas Animal Lovers Lhokseumawe (ALL) saja, namun juga dengan komunitas pecinta reptil di daerah lainnya. Mereka menganggap semua Komunitas Animal Lovers adalah keluarga. Tercermin dari pertemuan mereka yang intens, duka cita yang dirasakan bersama, bahkan sampai menampung anggota komunitas lain yang butuh tumpangan untuk menginap, dan banyak lagi lainnya.

b. Saling Membantu

Anggota Animal Lovers Lhokseumawe (ALL) selalu bersedia membantu dan menolong anggota yang mengalami musibah. Selain itu anggota Animal Lovers Lhokseumawe (ALL) juga tidak segan-segan memberi atau membantu kebutuhan pakan atau lainnya dalam hal perawatan hewan kepada anggota yang membutuhkan. Rasa saling membantu tidak hanya antar anggota saja, bahkan masyarakat biasa yang bukan merupakan anggota ALL juga akan tetap dibantu.

Selama ini yang meminta bantu adalah masyarakat yang pernah mengunjungi kegiatan gathering mingguan komunitas tersebut untuk meminta bantuan rescue hewan liar. Selain membantu me-rescue hewan yang dianggap dapat mengancam manusia, Animal

Gambar 1. Animal Lovers Lhokseumawe sedang sosialisasi Lovers Lhokseumawe juga terhadap pramuka penggalang mengenai pengenalan dan cara membuka diri dalam membantu masyarakat untuk mengatasi phobia reptil. 


\section{Nilai Pendidikan (Edukasi)}

Komunitas Animal Lovers Lhokseumawe dibentuk untuk menyatukan para penghobi memelihara reptil. Selain itu komunitas ini juga sebagai wadah transformasi informasi dan edukasi mengenai dunia reptil. Keinginan dari setiap upaya yang dilakukan ialah agar terciptanya keseimbangan ekosistem. Dengan menciptakan kebiasaan-kebiasaan bersahabat dengan reptil. Selain itu, paham akan nilai hidup berdampingan antara manusia dan satwa liar menjadi perhatian dari tujuan edukasi yang dilakukan.

Komunitas Animal Lovers Lhokseumawe (ALL), dalam edukasi terhadap masyarakat komunitas ini melakukan kunjungan ke sekolah-sekolah di sekitar Kota Lhokseumawe dan Aceh Utara. Mereka memberikan pengetahuan bahwa jenis ular tidak semuanya berbisa. Dari 2.735 jenis ular di seluruh dunia tidak kurang dari $10 \%$ yang berbisa.

Edukasi juga dilakukan terkait perilaku dalam menyikapi ketika masyarakat berhadapan dengan reptil, salah satunya seperti ular. Selain itu penanaman modal dasar terkait tentang upaya rehabilitasi dan konservasi juga dilakukan.

\section{Nilai Seni (Hiburan)}

Secara umum, seni bisa dikatakan sebagai sesuatu ciptaan manusia yang memiliki nilai keindahan (estetika) dan mampu membangkitkan perasaan orang lain. Seni memiliki beberapa fungsi, di antaranya ialah; Pertama, untuk memenuhi kebutuhan emosional. Untuk memenuhi kebutuhan emosional manusia memerlukan dorongan dari luar dirinya yang sifatnya menyenangkan, memuaskan kebutuhan batinnya.

Kegiatan dan aktifitas sehari-hari yang membuat kelelahan sehingga memerlukan rekreasi. Hal itu berlaku juga pada komunitas Animal Lovers Lhokseumwe, mereka bermain dengan reptil sebagai usaha untuk menghilangkan stress dari kepenatan aktivitas harian.

Kedua, sebagai media hiburan. Kesenangan dengan bermain bersama reptil, kemudian diungkapkan oleh Komunitas Animal Lovers Lhokseumawe dengan membuat kegiatan gathering. Kegiatan ini sebagai bentuk sosialisasi yang dilakukan untuk mengkampanyekan hubungan manusia dengan reptil. Dari kegiatan ini Komunitas Animal Lovers Lhokseumawe mempertunjukkan hewan-hewan reptil 
dan non reptil kepada masyarakat. Kegiatan ini juga sebagai ajang hiburan baik bagi pecinta reptil sendiri maupun masyarakat yang menyaksikannya. Gathering juga diharapkan dapat menghibur para masyarakat dengan melihat hewan-hewan reptil yang jarang dilihat pada hari biasanya.

5. Nilai Eksistensi Diri

Hobi memelihara reptil dikalangan masyarakat Kota Lhokseumawe masih terbilang sesuatu yang aneh. Terkadang melakukan sesuatu yang aneh juga merupakan suatu keunikan sendiri bagi para pelakunya. Karena hobi tersebut masih terlihat asing bagi kebanyakan masyarakat.

Kegiatan kemunitas melalui sosialisasi dan edukasi serta gathering memiliki norma yang mengikat pada setiap anggotanya. Kepatuhan terhadap hal-hal yang telah disepakati bersama membawa nilai kebersamaan sehingga berdampak pada peningkatan nilai eksistensi. Hal itu membuat kelangsungan dan keutuhan kemunitas ini terjaga. Dan kesediaan platform sosial media tentunya juga mendukung hal tersebut.

Kemudian untuk meningkatkan eksistensi, komunitas Animal Lovers Lhokseumawe mengikuti berbagai ajang perlombaan-perlombaan hewan reptil. Bahkan bukan hanya di wilayah Aceh saja, komunitas Animal Lovers Lhokseumawe juga mengikuti kontes-kontes yang diselenggarakan oleh Animal Lovers Indonesia.

Sosialisasi ke sekolah-sekolah, publikasi di media sosial dan mengikuti kontes untuk menampilkan ular-ular peliharaan menjadi upaya peningkatan eksistensi diri dan komunitas Animal Lovers Lhokseumawe. Hal tersebut menunjukkan bahwa setiap anggota menyadari apa yang dibutuhkan untuk meningkatkan eksistensi diri. Salah satunya ialah dengan bergabung dengan komunitas ALL yang dalam setiap kegiatannya selalu berhubungan dengan masyarakat.

Merujuk pada konsep hierarki kebutuhan Maslow, dapat dikatakan bahwa nilai-nilai tersebut muncul sebagai reaksi dari usaha memenuhi kebutuhan dasar yang dilakukan berdasarkan kesadaran diri para Animal Lovers Lhokseumawe.

\section{Relasi Antara Manusia dan Hewan}

1. Relasi antara Manusia dan Hewan dalam Kacamata Antropologi 
P.J. Ucko, Direktur Institut Arkeologi di University College London dalam Jurnal Balairung (2018;251) mengatakan bahwa, "garis batas antara manusia dan hewan tidak akan pernah tegas dan jelas. Maka, manusia akan selalu berusaha mendefinisikan kembali dirinya berdasarkan eksitensi hewan. Hal ini ditunjukkan dari produk budaya masyarakat dalam kaitannya dengan relasi terhadap hewan". Sehingga sampai saat ini perilaku manusia terhadap hewan masih berbeda satu sama lain. Hal tersebut sesuai dengan konteks budaya masyarakat setempat. (Sitohang, 2018;251)

Dalam kajian antropologi, kehadiran binatang merupakan bagian yang tidak terpisahkan dari kehidupan manusia. Manusia berinteraksi dan bahkan memiliki budaya-budaya yang berhubungan dengan binatang, baik dalam ritual, mata pencarian (ternak), maupun sebagai binatang peliharaan yang menjadi gaya hidup manusia.

Relasi antara manusia dan hewan sudah ada sejak jaman The Stone Age atau zaman batu. Pada awal mulanya hewan difungsikan untuk membantu pekerjaan manusia oleh karenanya hewan tidak bisa dipisahkan dari manusia karena interaksi ini sama-sama menguntungkan keduanya. Hewan-hewan ini dipelihara untuk memudahkan manusia dalam menjalani hidupnya. Hewan-hewan tersebut seperti anjing untuk berburu, sapi untuk menggarap sawah, kuda sebagai alat transportasi.

Namun seiring berjalannya waktu, hubungan di antara manusia dan hewan peliharaan menjadi lebih kompleks. Hewan dipelihara tidak hanya untuk membantu manusia saja, tetapi juga atas azas hubungan emosional, bahkan untuk meningkatkan status sosial pemiliknya. Hal ini dapat dilihat di zaman modern ini yang mana para pecinta hewan tidak segan-segan menghabiskan uangnya untuk memelihara hewan-hewan langka yang kebanyakan dari jenis reptil. Hewan-hewan ini kemudian dijadikan sebagai ajang pamer di antara sesama pencinta hewan tersebut.

Banyak daerah di dunia memiliki tradisi yang melibatkan hewan. Hal ini juga berlaku di Kota Lhokseumawe (Aceh). Masyarakat Kota Lhokseumawe mengorbankan domba, kambing dan sapi sebagai bagian dari tradisi. Artinya, hewan dibunuh untuk dijadikan makanan. Kemudian hewan juga berkedudukan sebagai mata pencarian manusia. Keadaan ini memposisikan hewan sebagai ternak yang 
kemudian mempengaruhi roda perekonomian masyarakat. Hewan-hewan yang dijadikan ternak pun tergolong banyak dan beragam tergantung budaya masingmasing daerah.

Selanjutnya hewan juga dijadikan sebagai binatang peliharaan. Hal ini berkaitan dengan hewan peliharan sebatas hanya sebagai gaya hidup (life style) manusia. Jenis hewan yang dijadikan peliharaan ini pun beragam. Tergantung pada minat dari setiap individu pemelihara. Seperti yang dilakukan oleh anggota Komunitas Animal Lovers Lhokseumawe yang memelihara reptil dan satwa liar lainnya sebagai hewan peliharaan.

2. Persepsi Komunitas Animal Lovers Lhokseumawe (ALL)

Penelitian fenomenologi berusaha memahami budaya melalui pandangan pemilik budaya atau pelakunya (Endraswara 2006: 65). Artinya, untuk menjelaskan fenomena hobi memelihara reptil ini memerlukan perhatian terhadap persepsi pandangan ALL terhadap lingkungan dan budayanya sehingga mengambil keputusan untuk memelihara reptil sebagai hobinya.

Wujud hubungan komunitas Animal Lovers dengan reptil yang berdasarkan motiv ingin mengenal, melindungi, dan melestarikan reptil memiliki persepsi dan cara yang berbeda dalam melindungi reptil. Usaha melindungi reptil dilakukan dengan cara menciptakan pola pemikiran pada masyarakat akan hidup berdampingan dengan hewan. Usaha tersebut dilakukan dengan melaksanakan kegiatan edukasi dan sosialisasi dunia reptil kepada masyarakat.

Komunitas ALL berpandangan bahwa hubungan manusia dan hewan itu harusnya seimbang. Karena baik manusia maupun hewan sudah diberikan tempat masing-masing untuk hidup. Kemudian antara manusia dan hewan semestinya hidup berdampingan, tidak ada yang bertindak mencelakai. Respon hewan, baik atau pun buruk tergantung cara manusia memperlakukannya.

\section{Memelihara Reptil sebagai Gaya Hidup Animal Lovers}

Gaya hidup (life style) merupakan cerminan keseluruhan pribadi yang berinteraksi dengan lingkungan. Keadaan itu kemudian dapat disimpulkan bahwa gaya hidup sebagai pola hidup seseorang yang dinyatakan dalam kegiatan, minat dan pendapatnya dalam membelanjakan uangnya dan bagaimana mengalokasikan waktu (Toffler dalam Walker, 2010:186). Gaya hidup dapat memberikan pengaruh 
positif atau negatif bagi yang menjalankannya, tergantung pada bagaimana orang tersebut menjalaninya. Begitu pula halnya pada pemilihan hobi memelihara hewan jenis reptil dalam kehidupan sehari-hari untuk memenuhi kebutuhan gaya hidup.

Hobi memelihara hewan reptil berbeda dengan memelihara binatang lainnya. Butuh tenaga ekstra dalam memeliharanya, hal ini dikarenakan reptil merupakan hewan yang sulit dipelihara dibandingkan dengan hewan pelihara lainnya. Tentunya keadaan ini menjadi dasar pembentuk aktivitas atau kegiatan Animal Lovers sebagai wujud pelaksanaan hobinya.

Namun, sebagai penghobi sekaligus pemelihara reptil, muncul kebiasaan baru dalam aktivitas sehari-hari anggota komunitas ini. Keadaan ini sebagai wujud akibat dari hobi yang ditekuni tersebut.Yang kemudian mempengaruhi gaya hidup mereka. Kemudian sebagai peminat dan pemelihara tentunya memiliki dorongan dan ikatan emosional terhadap hewan. Perilaku-perilaku yang dapat mencerminkan keterwakilan rasa sayang terhadap hewan akan dimunculkan. Di antara aktivitas yang menjadi kebiasaan-kebiasaan ialah;

1. Perhatian terhadap hewan

Perhatian tersebut diekspresikan dalam berbagai bentuk sikap, di antaranya; Pertama, peduli terhadap kondisi kebersihan reptil dengan rutin merendam atau memandikan serta menjemur hewan peliharaannya masing-masing. Kedua, memberi makan reptil (hewan peliharaan). Para anggota ALL selalu berusaha dalam menyediakan pakan hewan tersebut. Bahkan ada yang rela menunda membeli sesuatu yang lain hanya untuk agar dapat memenuhi kebutuhan pakan reptil tersebut. Ketiga, menyediakan tempat tinggal yang tepat untuk hidup reptil. Hal ini dilakukan untuk menjamin kenyamanan reptil. Sehingga terjaminnnya keberlangsungan hidup reptil dan hewan-hewan peliharaan lainnya.

2. Bermain dengan reptil.

Di sela waktu luang baik pagi maupun sore, para Animal Lovers mengahabiskan waktu dengan bermain bersama hewan yang dipelihara. Hal itu dilakukan sebagai upaya penghilang stres dari penatnya aktivitas atau kerjaan sehari-hari. Tentunya hal ini dipandang sebagai salah satu pengaruh positif dari hobi memelihara reptil. 
1. Perilaku-perilaku yang diuraikan di atas dalam memperlakukan, merawat, memberikan dan memilih makan yang terbaik, menjaga kesehatan, dan sebagainya melahirkan gaya hidup baru bagi pecinta reptil tersebut.

\section{Penutup}

Komunitas Animal Lovers merupakan satu-satunya komunitas pecinta reptil yang berada di Kota Lhokseumawe. Komunitas Animal Lovers Lhokseumawe (ALL) berdiri dengan maksud dan tujuan untuk menghimpun dan mewadahi para pemilik serta pecinta hewan baik reptil maupun non reptil agar bisa berkomunikasi, bersosialisasi dan berinteraksi secara positif.

Pencapaian tujuan pembentukan komunitas itu dilakukan dengan maksud untuk meningkatkan dan mengembangkan pengetahuan tentang binatang kepada diri sendiri dan orang lain. Mengadakan gathering untuk masyarakat ramai agar lebih mengenal tentang binatang yang berbahaya maupun tidak berbahaya. Serta menjadikan komunitas Animal Lovers sebagai tempat bersosialisasi, berbagi ilmu, informasi dan pengalaman baik dari anggota ke masayarakat maupun sebaliknya.

Hasil dari penelitian ini menujukkan bahwa ada beberapa nilai penting yang membuat lahirnya komunitas Animal Lovers Lhokseumawe, di antaranya: (1) nilai budaya, (2) nilai sosial, (3) nilai pendidikan (edukasi), (4) nilai seni (hiburan), dan (5) nilai eksistensi. Kemudian berdasarkan motiv dan nilai dalam pelaksanaan kegiatan hobinya, ada beberapa perilaku yang menunjukkan ekspresi sayang terhadap hewan di kalangan Animal Lovers Lhokseumawe, diatantaranya yaitu; perhatian terhadap hewan (menjaga kebersihan, memberi makan, dan menyediakan tempat tinggal), dan bermain dengan reptil. Perilaku tersebut cenderung menampilkan wujud relasi manusia dengan hewan di kalangan ALL dalam memelihara reptil.

Dalam kajian antropologi, kehadiran binatang merupakan bagian yang tidak terpisahkan dari kehidupan manusia. Manusia berinteraksi dan bahkan memiliki budaya-budaya yang berhubungan dengan binatang, baik dalam ritual, mata pencarian (ternak), maupun sebagai binatang peliharaan yang menjadi gaya hidup manusia. 
Animal Lovers Lhokseumawe memandang hubungan manusia dan hewan semestinya hidup berdampingan, manusia dan hewan semestinya hidup seimbang dan hewan dijadikan teman. Sebagai penghobi sekaligus pemelihara reptil muncul kebiasaan baru dalam aktivitas sehari-hari anggota komunitas ini. Keadaan ini sebagai wujud akibat dari hobi yang ditekuni. Kebiasaan-kebiasaan tersebut misalnya seperti setiap pagi Animal Lovers Lhokseumawe rutin merendam atau memandikan serta menjemur hewan peliharaannya masingmasing. Kemudian sebagai peminat dan pemelihara memiliki dorongan dan ikatan emosional terhadap hewan. Perilaku-perilaku yang dapat mencerminkan keterwakilan rasa sayang hewan akan dimunculkan. Di antaranya seperti menjamin kesejahteraan dari segi pakan, memberikan kandang yang layak serta menjaga kebersihan kandangnya dan menjaga kesehatan hewan peliharaan. Bahkan sampai pada tingkat menahan membeli yang tidak penting dulu, dan lebih mengutamakan membeli bahan pokok makanan hewan reptil tersebut 


\section{Daftar Pustaka}

Adi, Isbandi Rukminto. 2013. Intervensi Komunitas Dan Pengembangan Masyarakat Sebagai Upaya Pemberdayaan Masyarakat. Jakarta: PT Raja Grafindo Persada.

Endraswara, Suwardi. 2006. "Metode, Teori, Teknik Penelitian Kebudayaan (Ideologi, Epistimologi, dan Aplikasi”. Sleman: Pustaka Widyatama

Fimela.com, 2015.Suka hewan reptil?Ini penyakit yang bisa ditularkan peliharaan anda, diakses darihttp://m.fimela.com/parenting/read/3747137/suka-hewanreptil-ini-penyakit-yang-bisa-ditularkan-peliharaan-anda,pada tanggal 03 Desember 2019.

GOACEH.co. 2017.Animal Lovers kampanyekan bersahabat dengan ular piton, diakses dari https://m.goaceh.co/berita/baca/2017/09/01/anima-loverskampanyekan-bersahabat-dengan-ular-piton, pada tanggal 03Desember 2019.

Hanapi, N. (2017). Nilai Budaya Komunitas Bajo dalam Meningkatkan Motivasi Belajar Life Skill. JPs: Jurnal Riset dan Pengembangan Ilmu Pengetahuan , 9495.

Iskandar. 2016. "Implementasi Teori Hirarki Kebutuhan Abraham Maslow terhadap peningkatan kinerja pustakawan." Jurnal Ilmu Perpustakaan, Informasi, dan Kearsipan Khizanah AlHikmah, Vol 4, No 1 24-34.

Hgenboom, Melissa. 2015. bbc.com. Juni 17. Accessed Juni 28, 2020. https://www.bbc.com/indonesia/vert_earth/2015/06/150614_vert_earth_b inatangpeliharaan.

Kompasiana.com. 2020. kompasiana.com. Maret 03. Accessed Juni 28, 2020. https://www.kompasiana.com/komjenrg6756/5e5dda6b097f366b4510bed 2/pasang-surut-sejarah-hubungan-manusia-dan-hewan?page=1.

Keesing, Roger M. 1981. Antropologi Budaya "Suatu Perspektif Kontemporer". Jakarta:PT Gelora Askara.

Koenjaraningrat, 2003.Pengantar Antropologi Jilid-I.Jakarta: PT Rineka Cipta.

Koenjtaraningrat,2009.Pengantar Ilmu Antropologi, edisi revisi. Jakarta: PT Rineka Cipta.

Manis, Hoeda. 2017. Ensiklopedia Dunia Dalam Binatang:Fakta-Fakta Unik Dan Menarik Dunia Hewan.Yogyakarta: Ar-Ruzz Media.

Moleong, Lexy J, 2014. Metodologi Penelitian Kualitatif. Bandung: PT Remaja Rosdakarya.

Mugnifar Ilham, 2019. "Reptil-Pengertian, Ciri, Klasifikasi, Contoh, dan Gambar, diakses darihttps://materibelajar.co.id/reptil/, 16Januari 2020.

Mulyana, Deddy, 2001.Metodologi Penelitian Kualitatif. Bandung: PT Remaja Rosdakarya.

O.Hasbiansyah.(2008). Pendekatan Fenomenologi: Pengantar Praktik Penelitian dalam Ilmu Sosial dan Komunikasi. Jurnal Mediator, Volume 9, No 1.

Podo, Siwo Prayitno hadi, dkk. (2012). Kamus Besar Bahasa Indonesia. Jakarta Barat: PT Media Pustaka Phoenix. 
Aceh Anthropological Journal, Vol. 5, No. 1 , hlm: 64-82, April 2021

Profauna.net, 'Fakta tentang Satwa Liar Indonesia, diakses dari https://www.profauna.net/id/fakta-satwa-liar-di-indonesia\#.Xd-BVRgxcOM, pada tanggal 03 Desember 2019.

Sitohang, L. R. (2018). Tim Ingold: Manusia dan Hewan Semestinya Saling Berbagi Kehidupan. Balairung: Jurnal Multidisipliner Mahasiswa Indonesia Vol.1 No.2 , 251. 